\title{
Latin America's Neocaudillismo: Ex-Presidents and Newcomers Running for President ... and Winning
}

Javier Corrales

\begin{abstract}
Latin Americans have been voting for a surprisingly large number of ex-presidents and newcomers in presidential elections since the late 1980s. This article looks at both the demand and supply sides of this phenomenon by focusing on economic anxieties and party crises as the key independent variables. Sometimes the relationship between these variables is linear: economic anxieties combined with party crises lead to rising ex-presidents and newcomers. At other times the relationship is symbiotic: the rise of ex-presidents leads to party crises, economic and political anxieties, and thus the rise of newcomers. This article concludes that the abundance of ex-presidents and newcomers in elections-essentially, the new face of Latin America's caudillismo-does not bode well for democracy because it accelerates de-institutionalization and polarizes the electorate.
\end{abstract}

$\mathrm{P}_{\mathrm{t}}$ residential elections in Latin America since 1988 exhibit an unusual trend. A large number of former presidents have been running for office and often winning. Counting only candidates who are not trivial-that is, who obtain more than 10 percent of the vote-at least one ex-president has run in roughly half the elections in which ex-presidents were constitutionally allowed to compete. They have won in almost 40 percent of the races. At the same time, the number of political newcomers - that is, candidates with virtually no political experience-is also large: nontrivial newcomers have competed in almost 20 percent of all elections. Latin Americans are displaying an electoral preference for two quite distinct candidates: ex-presidents and newcomers.

This is an odd phenomenon. The electoral salience of ex-presidents and newcomers is a departure from the experience of democracies in Europe, where these types of candidates are infrequent. This trend also contradicts prominent theories about electoral choice, such as the view that electoral choice is contingent on economics and curricula vitae (Alesina 1994). In moments of economic downturn, according to this theory, voters tend to prefer candidates with resumes that combine reliability (i.e., a proven record of experience in office) with some detachment from the status quo that presumably makes the candidate more able to pursue change (Dalton and Wattenberg 1993). In Latin America, 
however, instead of a balance between reliability and relative autonomy, voters are exhibiting an extreme "either-or" preference. The vote for an ex-president represents a choice for extreme reliability at the expense of renewal, and the vote for a newcomer, the reverse. In short, contrary to the cliché, Latin Americans are voting for the devils they know and the devils they don't.

Whereas studies of incumbent presidents boomed in the 1990s, studies of opposition candidates are scarce. We know a lot about how presidents act differently from prime ministers in parliamentary systems, respond to economic crises, staff their cabinets, confront or provoke constitutional crises, and interact with congress, their own parties, and economic actors. We know far less about the type of candidates who challenge incumbents. This article provides evidence that in Latin America since the 1980s, incumbents are often being challenged by ex-presidents and, increasingly, by newcomers.

To explain the salience of ex-presidents and newcomers, this article will explore both the demand and the supply sides. The demand side answers the question, why might the electorate crave this type of candidate? The argument here draws from existing works that posit that the Latin American electorate has been besieged, at least since the 1970s, by economic anxieties. This anxiety produces a demand for redemptory candidates, which is precisely how these ex-presidents and newcomers bill themselves.

However, the rise of ex-presidents and newcomers is contingent not only on what the electorate wants but also on what the political system supplies-what in Latin America is often referred to as the oferta electoral. Because the menu of candidates in any given presidential election depends largely on decisions made by political parties-and their capacity either to filter or to promote certain candidates-examining the rise of ex-presidents and newcomers requires looking at the state of political parties.

Statistical analysis provides some preliminary clues. For newcomers, the results support both demand- and supply-side arguments. Newcomers emerge in the context of economic volatility and party system fragmentation. This party fragmentation finding lends itself to two interpretations. One is that party fragmentation represents a relaxation in the barriers to entry for new figures. The other is that newcomers are responding to party crises (when fragmentation is the result of parties' undergoing crises). Both interpretations point toward supply-side forces, a topic that is further explored through qualitative analysis.

For ex-presidents, however, the evidence on behalf of demand-side forces is not as strong statistically, but the evidence on behalf of supplyside forces is clear in the qualitative analysis. It will show that ex-presidents resurface because they "can," due to their unrivaled political 
assets; when the regime opens up, which allows the ex-president's political assets to show their weight; and most important, when their parties are too weak to block them.

The additional argument inherent in this analysis is that the rise of newcomers and ex-presidents is often mutually reinforcing. Both types emerge in the context of party crises, yet each type can exacerbate these crises. When ex-presidents resurface, for instance, they provoke deep fissures within their parties and the possibility of subsequent elite defections, voter dealignment, electoral polarization, and even governance difficulties. In essence, the return of ex-presidents leads to party system fragmentation and economic anxieties, the very same conditions that lead to newcomers. The rise of ex-presidents and newcomers is thus causally interconnected. Newcomers themselves, if elected, face the animosity of existing political parties, which often compels them to respond with undemocratic decisions. These decisions may both weaken parties further and polarize the electorate.

In sum, the abundance of ex-presidents and newcomers running for office-and winning-does not bode well for democracy in Latin America. In many ways, these candidates are the new face of Latin America's old caudillismo. Like the old caudillos, Latin America's contemporary lingering ex-presidents and suddenly rising newcomers are both a symptom and a cause of de-institutionalization and polarization.

\section{The Length of Political Resumes}

To begin with, some labels should be clarified. In any given presidential election, candidates differ according to how much information is available about their programs and friends. Program means the type of diagnosis, policy, or ideology offered; or, where they want to take the country. Friends are the types of political alliances candidates establish with other political actors; or, which partners they want to govern with. The longer candidates have been in politics (i.e., the longer their political resume) and the more scrutiny their careers have received in the media and elsewhere, the more information is available to the public about their program and friends.

Voters thus confront asymmetrical information about candidates. The concept of asymmetrical information has gained prominence in political science as an explanation for accountability failures (Schedler et al. 1999). Although we know that voters do not often need or rely on abundant information to make political decisions (Popkin 1992), it is now standard to evaluate regimes, and thereby voters, according to how they respond to information asymmetries. Therefore, in terms of available information, candidates can be ranked as follows: 
1. Incumbents (Is). These are candidates who run for president (or prime minister in parliamentary systems) while serving in that office. Incumbents are the most widely known candidates, although not necessarily the most popular. Citizens tend to have far more information on incumbents than other candidates (Downs 1957) not only because of their prominent position, but also because they receive more media attention (Popkin 1992, 65-67). ${ }^{1}$

2. Ex-presidents (XPs). These are persons who were presidents (or prime ministers, in parliamentary systems) during some term prior to the one in which the electoral contest is taking place. ${ }^{2}$ After incumbents, expresidents are typically the best-known candidates. In terms of information available to voters, ex-presidents may even surpass incumbents in one respect: voters have information not only about how ex-presidents governed but also how they behaved as opposition figures. ${ }^{3}$

3. Ex-presidents' Names (XPNs). These are candidates who have the same last name as an ex-president due to a familial relationship (such as a spouse, former spouse, or family member). These candidates are often considered the "continuity ticket," since many voters and analysts expect them not to deviate much from the programs and friends associated with the presidents whose last name they bear.

4. Newcomers (Ns). Newcomers, or "outsiders," as they are sometimes called, are harder to define. Analysts agree that in terms of experience, they occupy the opposite end of the spectrum from incumbents and ex-presidents. But scholars disagree about who really counts as a newcomer. Some scholars propose highly restrictive definitions based on visibility: a newcomer is someone with no national reputation before the electoral campaign. Other definitions are less restrictive: a person without electoral experience only in national politics, such as a governor. Still other scholars choose to believe simply what the candidates say: those who describe themselves as newcomers, or simply anti-establishment, are accepted as such.

Each definition has problems. The more restrictive definition excludes candidates who lack experience in professional politics but are nonetheless well known, such as coup instigators Hugo Chávez in Venezuela and Lucio Gutiérrez in Ecuador. These candidates were national celebrities but still politically untested when they ran for president. This definition also excludes business magnates, whose fortunes and lifestyles may be well known but whose politics are not. Because the motivation for this research is to study voter choice and political information, the crucial criterion here is lack of campaign, electoral, and administrative experience, not necessarily name recognition.

The problem with a less restrictive definition is the opposite: it makes room for individuals whose politics are well known. Because information about their programs and friends is abundant, it is hard to include 
them in the same category as a truly inexperienced newcomer with a thin resume. The problem with self-identification is that at best, it tells voters about intentions rather than previous experience. Thus, it is a misleading criterion for measuring the degree of information that candidates offer about their record.

Since the goal here is to understand the appeal to voters of someone with a very brief political resume, this study follows Linz (1994, 26) in defining newcomers as those who run for president with no prior electoral experience (running for political office) and no major public administration experience. This is a strict definition. To meet this definition, the candidate need not be a complete political cipher or a total stranger (he or she might have been involved in national politics through party activity, military activity, or simply by being a celebrity). However, the candidates must be electoral and administrative neophytes. It should be noted that given the first criterion, candidates can qualify for this category only once-the first time they run.

5. Low-experience candidates (LEs). These are candidates with some electoral experience but in relatively secondary posts (e.g., congressional deputies, small-town mayors, elected leaders of small civil society organizations, losing candidates for the governorship of minor provinces). The definition also includes candidates with experience in one presidential race but who obtained less than 10 percent of the vote. These candidates are not newcomers, because they have had some electoral experience. Yet information about their program and friends is arguably obscure because they competed in low-salience arenas. This category also includes former ministers who run for office after taking a long break from domestic politics (e.g., Javier Pérez de Cuellar in Peru, 1996, who had not held a national post since the early 1980s) and cabinet members who served briefly-less than six months—-such as Rafael Correa in Ecuador, 2006.

6. Experienced Candidates. This is a residual category. It captures candidates who are neither excessively tested (incumbents and ex-presidents) nor inexperienced (newcomers and low experience). Examples include executive branch experience (previous cabinet members, including vice presidents, although note the exception for low-experience candidates); executive experience at the provincial level (governors elected by direct election, mayors in capital or large cities); former presidential candidates who won more than 10 percent of the vote; senior military officers who held positions close to the executive branch; senators in the national legislature; leaders in the lower chamber of the national legislature (e.g., leader of the majority or the opposition); and primary leaders of a national party that has at least 10 percent of total congressional representation. 


\section{Data ANd Trends: Latin America VERSUS EUROPE}

Appendixes 1 and 2 list all the incumbents (I), ex-presidents (XPs), expresident's names (XPNs), newcomers (Ns), and low-experience candidates (LEs) who ran for president in every election in 21 Latin American and 10 European countries from 1988 to 2006 and who obtained more than 10 percent of the vote. The reason for not coding candidates who obtain less than 10 percent is to exclude candidates with minimum electoral appeal (and because obtaining biographical data on some of these minor candidates is a challenge). The data were obtained by studying published biographies of candidates and coding them according to these definitions.

In terms of the frequency with which incumbents run for office, Latin America and Europe are not that different: incumbents ran in 65.4 and 63.6 percent of races, respectively. However, in terms of ex-presidents and newcomers, the two regions are far apart. In Latin America, a total of 38 ex-presidents ran for office obtaining more than 10 percent of the vote. ${ }^{4}$ Ex-presidents competed in exactly half of the races in which they were allowed to compete. On average, there was at least one ex-president for every two presidential elections in Latin America (see table 1). Several races even featured two ex-presidents (Argentina 2003, Bolivia 1997 and 2002, Haiti 2006, Suriname 2000 and 2005). In Europe, only 17.4 percent of races featured former prime ministers or ex-presidents, an average of one ex-president for every five elections. ${ }^{5}$

Candidates running with an ex-president's last name are also frequent in Latin America, appearing in 16.1 percent of elections, yet virtually nonexistent in Europe. ${ }^{6}$ These candidates seem to occur in countries in which ex-presidents are not allowed to run (three times in Mexico, three times in Costa Rica, and twice in Colombia), but not exclusively (e.g., Eduardo Frei and Arturo Alessandri in Chile, Jacobo Bucaram in Ecuador, Mireya Moscoso and Martín Torrijos in Panama).

In Latin America, 18 newcomers have run for president obtaining more than 10 percent of the vote. ${ }^{7}$ Newcomers appeared in 17 contests, or 19.5 percent of the elections in the dataset (table 2). Considering that a candidate can only be a newcomer once, this number is significant. In Europe, newcomers have appeared in only 6.5 percent of the races. ${ }^{8}$ Low-experience candidates (LEs) obtaining more than 10 percent of the vote are more common in Europe, appearing in 21.7 percent of elections, in contrast to 12.6 percent for Latin America.

Ex-presidents and newcomers are not only more frequent, but also electorally more successful in Latin America. The average vote for expresidents in Latin America is 30.9 percent versus 25.8 percent in Europe. The greater appeal of ex-presidents is evident even after 
Table 1. Ex-presidents (XPs) and Candidates with Ex-presidents' Names (XPNs)

\begin{tabular}{lcr}
\hline \hline & Latin America & Europe \\
\hline Elections allowing XPs & 66 & 46 \\
Number of elections in which XPs compete & 33 & 8 \\
Average number of XPs in elections in which they & & \\
$\quad$ can compete & 0.58 & 0.20 \\
Percent of elections in which XPs can and do compete & 50.00 & 17.39 \\
Average number of XPs and XPNs in all elections & 0.62 & 0.20 \\
\hline \hline
\end{tabular}

excluding the largest outlier, Jean-Bertrand Aristide in Haiti, who obtained 92 percent of the vote. Excluding Aristide, the Latin American average is still ahead at 29.2 percent. Newcomers also obtain more votes in Latin America: 25.7 percent versus 17.2 percent. Only LEs appear to receive a similar share of the vote.

In sum, the phenomenon of the devil we know (XPs plus XPNs) and the devil we don't know (Ns) is distinctively large in Latin America. In combination, these candidates represent 30.6 percent of all candidates in Latin America, more than three times larger than the amount in Europe, 8.22 percent.

\section{The Demand SIDE}

Any explanation for the salience of newcomers and ex-presidents in Latin America must incorporate the demand side (why does the electorate opt for ex-presidents and newcomers?) and the supply side (what are the institutional conditions that give rise to these candidates?).

Prospect theories offer a first set of clues for understanding the demand side. These theories try to ascertain the conditions under which actors make seemingly "insane" choices. One version suggests that when confronting change or uncertainty, people tend to value that which they already own more than other items, the so-called endowment effect (Thaler 1980). Another version suggests that actors become more accepting of risk when they face losses or uncertainties (Weyland 2002). These insights shed some light on the demand for both ex-presidents and newcomers.

For instance, the greater information that ex-presidents provide compared to other candidates might make some voters feel that in a certain sense they "own" that candidate. Moreover, the appearance of newcomers as unconnected to vested interests makes ordinary citizens feel that newcomers "belong" to them rather than to elites. Likewise, choosing an $\mathrm{N}$ or LE, which is the equivalent of going on a blind date, can be 
Table 2. Newcomers (Ns) and Low-Experienced (LE) Candidates

\begin{tabular}{lrr}
\hline \hline & Latin America & Europe \\
\hline Number of elections in which Ns compete & 17 & 3 \\
Average number of Ns in elections & 0.21 & 0.07 \\
Percent of elections in which Ns compete & 19.54 & 6.52 \\
Number of elections in which LEs compete & 11 & 10 \\
Average number of LEs in elections & 0.14 & 0.26 \\
Percent of elections in which LEs compete & 12.64 & 21.74 \\
\hline \hline
\end{tabular}

explained in terms of greater risk taking in the face of adversity or desperation. Even the choice for an XP could be labeled as risky. While, on the one hand, it is a safe choice because it is the candidate most familiar to voters, on the other hand, it is a risky choice because there is no assurance that past mistakes will be avoided or that sequels will be better. In short, both options-voting for XPs or Ns-offer the promise of escaping an unacceptable present through an odd combination of voters' feelings of connectedness and a willingness to overlook negative information or information deficits.

Why is this type of attitude toward candidates far more predominant in Latin America than in Europe? The answer may be different levels of economic anxiety, itself perhaps the product of four decades of drastic economic change in the region. In the 1970s, Latin America experienced extreme forms of statism (Kucynski 1988); in the 1980s, extreme policy and macroeconomic instability (Teitel 1992; Edwards 1995); in the early 1990s, extreme shock therapy, economic liberalization, and policy swings (Stokes 2001; Sheahan 2002; Corrales 2003; Williamson and Kucynski 2003); and in the late 1990s, external shocks followed by growth again (Zettelmeyer 2006). In addition, since the 1950s, Latin America (along with Africa) has had more debt defaults or restructurings per decade than other regions. Periods of strong growth have been brief and have often ended in deep recessions (Singh et al. 2005; Singh 2006; Sturzenegger and Zettelmeyer 2007). This volatile economic performance contrasts with postwar Europe's relative economic stability and gentler retreat from the welfare model (Huber and Stephens 2001, 32), and may explain Latin America's greater anxieties. Therefore, the following hypothesis can be proposed:

Hypothesis 1. More economic and political volatility or adversity yields votes for newcomers and ex-presidents in Latin America. 


\section{The Supply Side: Institutional Causes}

Whether ex-presidents and newcomers run depends not just on what voters may demand, but also on what institutions offer. Two sets of institutional factors may be critical. The first is the well-studied difference between parliamentarism and presidentialism; the second, party crisis.

One explanation for the larger supply of ex-presidents and newcomers in Latin America relative to Europe may have to do with differences between presidential systems (prevalent in Latin America) and parliamentary systems (prevalent in Europe). Political advancement in parliamentary systems is, for the most part, designed to be difficult for newcomers. Parliamentarism encourages the selection of long-term party leaders as prime ministers and restricts access for newcomers. In contrast, presidential regimes rely on direct primaries, which create opportunities for newcomers (Linz 1994).

However, it is important not to overstate the different effects of parliamentarism and presidentialism. The barriers posed by parliamentarism are not insuperable, and presidential systems can also pose institutional barriers to ex-presidents, as Linz (1994, 18) recognizes, and even to newcomers. These barriers differ from country to country and election to election, and quite often depend on a factor other than regime type; namely, the strength of political parties. Strong, institutionalized parties not only help "control incumbents" (Stokes 2001, 102-21), but also the oferta electoral. As Siavelis and Morgenstern (2004) argue, in strong, institutionalized parties, internal party rules and protocols work to discourage both newcomers and ex-presidents. At the very least, the more institutionalized a party, by definition, the more avenues exist for party leaders, other than traditional party bosses like ex-presidents, to assume leadership (Levitsky and Cameron 2003) and to filter out radical, inexperienced candidates. Consequently, for ex-presidents and newcomers to emerge, some form of party breakdown must be in progress (Mainwaring 2006a, b). Therefore, the following hypothesis is offered to account for part of the supply side:

Hypothesis 2. As party crisis increases, the vote for XPs and Ns rises.

\section{Quantitative Evidence: Model, VARIABLES, AND RESUlTS}

Regression analysis provides one way to test both demand- and supplyside forces. ${ }^{9}$ The dependent variable is "how well" newcomers and expresidents perform electorally. Two complications emerge in creating this dependent variable. The first is that "how well" a candidate per- 
forms electorally depends on how many other candidates compete. Obtaining 40 percent of the vote when competing against one candidate is less impressive than obtaining the same share of the vote against multiple candidates. To account for this relativity, each dependent variable was normalized by subtracting the average number of votes received by other candidates from the total number of votes received by either the ex-president or the newcomer. ${ }^{10}$

The second complication is boundedness. The dependent variable has two bounds: candidates can obtain no more than 100 percent of the vote (the upper bound) and no less than 0 percent (the lower bound). No candidate ever reaches the upper bound, and candidates who win less than 10 percent were excluded to filter out trivial candidates. To account for these bounds, the normalized votes for newcomers and expresidents were transformed using a logistic function. ${ }^{11}$

To measure the demand side, one political variable and two economic variables were used. The political variable is regime type. Under the assumption that declines in civil and political liberties constitute adversity for the majority of citizens, regime characteristics is proposed as a measure of demand (although, as will be discussed later, it could also be considered a measure of supply). The specific source used was the Freedom in the World Index from Freedom House, which has become a widely used measure of the extent to which states and citizens respect political and civil liberties across societies. The two economic variables are changes in economic growth and changes in inflation rates (rather than mere actual levels of economic growth and inflation rate). Alternative measures were tried (see Westhoff and Corrales 2008), but the simplest model using year-to-year differences yielded the best results, and is therefore reported here.

Measuring party crisis presented a bigger problem: no standard measurement of party crisis exists. The best alternative to be found is the effective number of parties (enp), which was calculated based on party seats in the lower house in bicameral legislatures and in the whole chamber in unicameral legislatures. ${ }^{12}$ Unquestionably, enp is an unreliable measure of party crisis. While all party systems undergoing a party crisis will display a rising number of parties, not all fragmented party systems reflect parties in crisis. Lacking a better measure of party crisis, however, this study follows Mainwaring (2006b) in choosing enp as an approximation, however imperfect, of possible party crisis. (See the statistical appendix for more details on these technical issues). ${ }^{13}$

Table 3 reports the best statistical regression models obtained. To account for heteroskedasticity, the generalized least squares method was used. Fraudulent or highly irregular elections were excluded. ${ }^{14}$ Elections banning ex-presidents were excluded from the ex-president regressions. 
Table 3. Regression Results for Newcomers and Ex-presidents

\begin{tabular}{lccccc}
\hline \hline & \multicolumn{2}{c}{ Latin America } & & \multicolumn{2}{c}{ Europe } \\
\cline { 2 - 3 } \cline { 5 - 6 } $\begin{array}{l}\text { Regression } \\
\text { Dependent }\end{array}$ & 1 & 2 & & 3 & 4 \\
Variable & & & & \\
\hline C & $-.889^{* * * *}$ & $.219^{* * *}$ & & $-.305^{* * * *}$ & $-.685^{* * * *}$ \\
& $(-7.27)$ & $(1.94)$ & & $(-4.47)$ & $(-5.25)$ \\
gdp_cap_gth_dif & $.0260^{* * * *}$ & $.0320^{* * *}$ & & -.0142 & .0117 \\
& $(2.74)$ & $(3.99)$ & & $(-1.13)$ & $(.53)$ \\
infl_gdp_dif & $.000271^{* * * *}$ & $-.000112^{* * *}$ & -.00630 & $-.0264^{*}$ \\
& $(2.67)$ & $(-1.91)$ & & $(-1.06)$ & $(-1.35)$ \\
enp & $.0819^{* * * *}$ & $-.00352^{* *}$ & $.0782^{* * *}$ & $.0632^{* * * *}$ \\
& $(3.26)$ & $(-1.51)$ & & $(11.27)$ & $(4.00)$ \\
fh_civillib & $.142^{* * *}$ & $-.164^{* *}$ & & 0.0073 & -.0523 \\
& $(4.93)$ & $(-5.05)$ & & $(.22)$ & $(.80)$ \\
Obs & 84 & 63 & & 45 & 45 \\
\hline \hline
\end{tabular}

One-tail significance levels: ${ }^{* * *}$ significant at 1 percent level; ${ }^{* *}$ significant at 5 percent level; * significant at 10 percent level.

The results for Latin America (regressions 1 and 2) are stronger than for Europe (regressions 3 and 4). The variables testing the demand side (the economic growth acceleration, inflation acceleration, and declining civil and political liberties) are more significant in Latin America. In contrast, demand-side indicators are not significant for Europe. The supplyside variable (enp) is significant across both Latin America and Europe, albeit less so for Latin American ex-presidents. These results confirm the two hypotheses.

Nevertheless, some unexpected results did emerge from the Latin American regressions. First, the positive coefficient for growth acceleration is surprising. On the one hand, the notion that economic fluctuations influence the vote for newcomers and ex-presidents in Latin America is consistent with the demand-side hypothesis presented in this paper. On the other hand, the positive sign shows that these candidates do better in the context of expanding rather than contracting growth, which is somewhat at odds with prospect theories.

Second, for Latin American ex-presidents (regression 2), the inflation accelerator variable is significant at the 5 percent level (rather than the 1 percent level found for Latin American newcomers), and the sign is different in relation to Latin American newcomers (negative rather than positive). Furthermore, inflation acceleration stimulates newcomers in Latin America (which is consistent with prospect theories) but depresses 
ex-presidents, which suggests that factors other than mere responses to economic crisis are influencing the vote for ex-presidents.

Third, the regime variable takes a different sign for ex-presidents (negative rather than positive). Newcomers emerge as authoritarianism increases (which is consistent with crisis-response arguments), but expresidents are less likely to succeed in less politically free states. One possible reason for this is that in less free states, where state officials are concentrating more power and curtailing political and civil liberties, incumbents are more likely to impose restrictions on known political rivals; ex-presidents are obvious targets. Newcomers, however, are by definition harder to pre-identify, and thus can escape the radar screen of more restrictive regimes. In short, as political liberties decline, voter demand for newcomers increases, and so does the capacity of newcomers to escape restrictions imposed by the regime, at least more than is the case with ex-presidents. In this sense, regime variables can be both a demand stimulus (for newcomers) and a determinant of supply (for both ex-presidents and newcomers)

This quantitative analysis permits three overall conclusions. There is evidence of demand-side and supply-side forces explaining Latin America's Ns and XPs; demand-side factors are less significant in Europe. The party fragmentation variable plays a role in explaining both newcomers and ex-presidents in both Latin America and Europe. Furthermore, the supply of ex-presidents in Latin America remains a bit mysterious, and less influenced by crisis factors than prospect theory would suggest. A more powerful explanation for ex-presidents is needed.

Before proceeding with such an explanation, it is worth stating that these statistical results must not be taken as conclusive. For one thing, the number of observations is small. The period studied is too limited, accounting mostly for growth years rather than the recession and highinflation years of the 1980s, which might explain the surprising finding that growth is associated with newcomers. In addition, the variable enp remains an unreliable measure of party crisis. In short, although the regressions show that supply and demand factors play a more significant role in Latin America, they are not definitive. The regressions do not test the more intriguing hypothesis that there might be a symbiotic relationship among XPs, Ns, and party crisis.

To explore that hypothesis, we still need a more nuanced understanding of how economic conditions and party crises may be affecting the supply and demand sides. From the statistical analysis, two new questions emerge: why do newcomers in Latin America do better in conditions of both positive economic change (growth acceleration) and crisis increase (inflation acceleration); and might there be a more nuanced way to evaluate the party crisis variable? The regressions confirm that party variables matter, so exploring this issue further 
seems pertinent. Qualitative evidence can be used to address these two questions.

\section{ReFining The ECONOMIC ANXIETY EXPLANATION}

Why does economic change in either direction-positive (growth acceleration) or negative (inflation acceleration)_help Latin American newcomers electorally? It is easy to understand why rising economic crisis in the form of rising inflation produces anxiety, and thus electoral demand for less conventional candidates. But why should growth acceleration have a positive effect? The literature on the political effects of economic growth provides an answer.

This literature emphasizes that "economic losers" exist in both fastgrowing economies and crisis-ridden countries. Since the heyday of modernization theory in the 1960s, scholars have theorized about the social disruptions that growth can generate, possibly leading to political anxieties (Huntington 1968). And in the 1990s, we learned that even economic winners experience anxieties related to uncertainty about the reform process, the sustainability of economic gains, or the prospect of improvements in noneconomic domains, such as institutional transparency (see Fernández and Rodrik 1991; Rodrik 1996; Lora and Panizza 2003). In addition, some high-growth countries in the 1990s also experienced rapid policy changes, which generated "drastic" and "volatile" changes in macroeconomic performance and income levels (Huber and Solt 2004). They also liberalized trade, which stimulated growth but generated disruptions, such as large internal migrations and exposure to volatile markets and financial flows (World Bank 2002).

Because of historical economic volatility, it is less surprising that Latin American voters since the 1980s would be sensitive to economic fluctuations in choosing candidates. Compounded by other maladies, such as corruption and street crime-what in Latin America is commonly referred to as impunidad and inseguridad-economic anxieties explain why levels of political discontent (defined as dissatisfaction with incumbents) and "disaffection" (defined as estrangement from political institutions and politics) are higher in Latin America than in Europe (Gunther et al. 2007). This political climate of discontent and disaffection produces fertile ground for the type of "insane" choices (blind dates with newcomers or blindness to the faults of ex-presidents) that prospect theory predicts.

Examples of these responses are Venezuela and Ecuador, on the one hand, and Peru and Bolivia, on the other. The former are cases of countries engrossed in economic crisis and lagging in reform; the latter are 
cases of aggressively reforming, growth-oriented countries in the 1990s. Yet in all four, electoral politics have been dominated by XPs, Ns, LEs, and Is, leaving little room for any other type of candidate (see table 4).

Nevertheless, there are limits to the economic anxiety hypothesis. It is simply impossible to predict the incidence of ex-presidents and newcomers based on economic performance alone. Noticing precisely this conundrum, Hagopian (2005) suggests that something else must mediate citizens' political response to endemic economic anxieties. This "something else," she argues, is political representation: where representation is weak, which typically means that parties are weak, citizens are more likely to respond by favoring escape options.

\section{Party Crisis and the Rise of XPs}

The regressions may not have shown as strong a correlation between party fragmentation and the rise of ex-presidents, but a closer look at "typical" cases reveals that ex-presidents often stage their comeback in the context of crises within their parties. ${ }^{15}$ These crises may or may not occur in contexts of party fragmentation. Two types of party crisis act as triggers: division among party elites prompted by ideological disputes, a huge electoral defeat, or both; and a major voter "dealignment," defined as a devastating break of a traditional link between party and constituency (Domínguez and Giraldo 1996; Hagopian 1998; Roberts and Wibbels 1999; Coppedge 2003; Mainwaring 2006b). Party crises provoke ex-presidents' comebacks by offering the motivation (the expresident returns to save the party), and by offering reduced resistance.

Venezuela is a paradigmatic example. The country began to experience the first type of party crisis around 1987-90 (within the party Acción Democrática), and then it succumbed to both types of party crises by 1993. Carlos Andrés Pérez rose in 1988 when his party, AD, was facing a deep policy debate regarding whether or not to liberalize Venezuela's political system by allowing direct elections of governors, mayors, and party primaries. Rafael Caldera emerged in 1993 when COPEI, the SocialChristian party, was deeply split about how to respond to the two coup attempts in 1992 (specifically, whether to impeach Pérez and whether to roll back economic reforms). Then dealignment reached dramatic proportions across all major parties (see table 5).

Examples extend beyond Venezuela. Gonzalo Sánchez de Lozada in Bolivia made his return in 2002 in the context of dramatic party dealignment, especially among indigenous groups. Efraín Ríos Montt in Guatemala tried to make his comeback in 2003 when his party was facing a crisis over an economic slowdown, a rising political left, allegations of corruption, and mishandling of tax reform. In Haiti, Aristide 


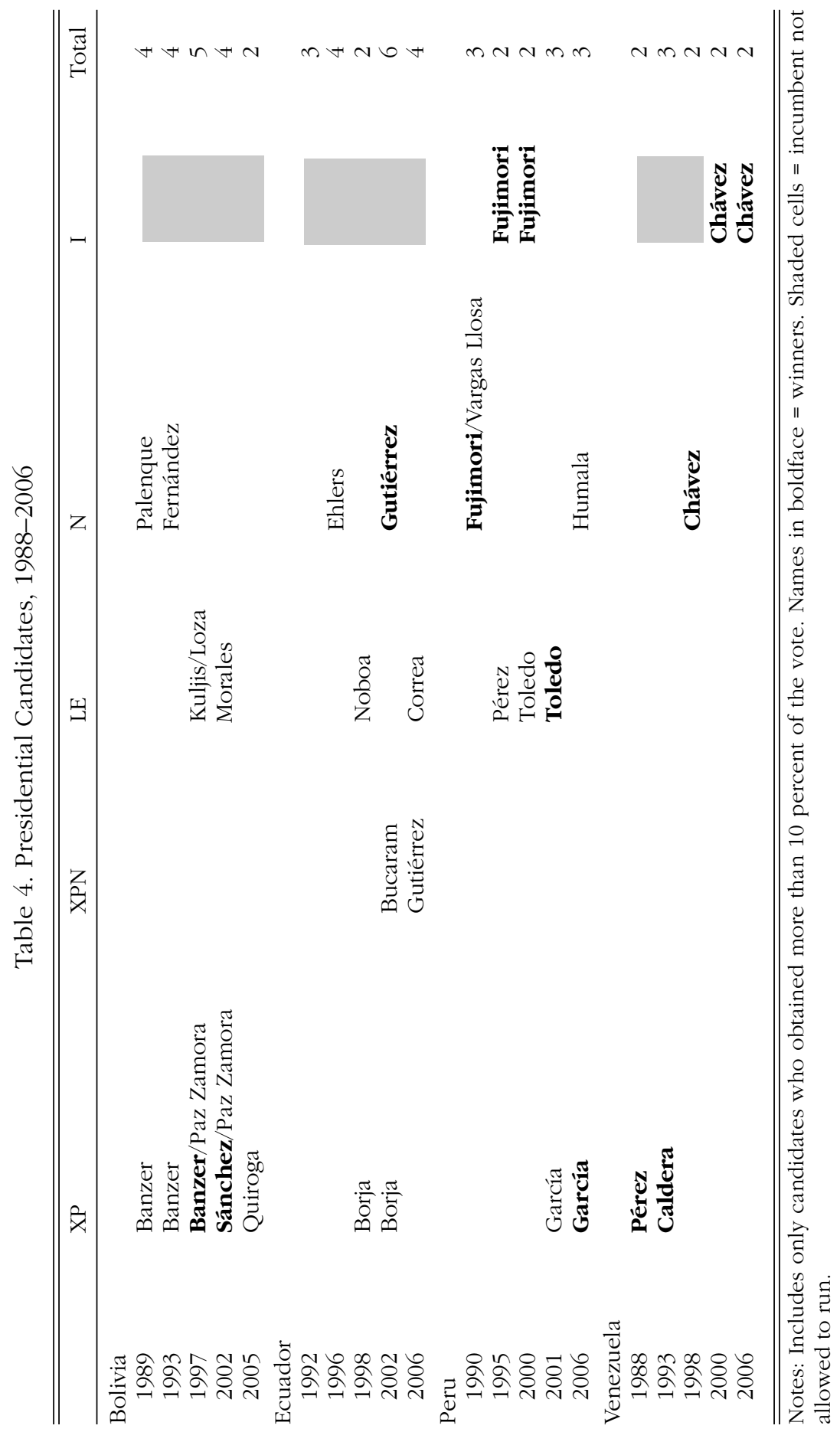


Table 5. Venezuela: Loyalties to Traditional Parties (AD, COPEI, MAS) (percentage)

\begin{tabular}{lccccc}
\hline \hline & 1973 & 1983 & 1993 & 1998 & 2000 \\
\hline Party activists and sympathizers & 45.9 & 35.3 & 27.8 & 14.0 & 10.8 \\
\hline \hline
\end{tabular}

Source: Based on public opinion polls, as per Molina 2000, 53.

re-emerged in 2000 in the context of a severe crisis in the Lavalas Party (partly induced by Aristide himself); and René Préval returned in 2005 to fill the political vacuum created by the forced resignation of Aristide in 2004 and the prevalence of armed groups both inside and outside the hegemonic party.

In Peru in 2001, Alan García resurfaced in the midst of the collapse of both his own party (APRA) and the ruling party following President Alberto Fujimori's resignation. In Argentina, Carlos Menem returned in 2003, after the ruling coalition collapsed in 2001 and a major debate broke out within his own Peronist party about the proper response to the country's financial crisis. In Costa Rica, Oscar Arias regained the nomination of his party, the PLN, in 2005 after the deputy Ottón Solís defected to form the Partido Acción Ciudadana in the 2002 elections.

Why do ex-presidents tend to prevail within their parties? The simple answer is that ex-presidents are hard to defeat. Ex-presidents enjoy virtually unrivaled political assets, not just within their parties but across the entire political system. By virtue of having been president, ex-presidents have a core of loyal supporters left over from their time in office. Many of these supporters remain in powerful positions and, through them, ex-presidents retain links with key national institutions (e.g., seats and allies in congress; friends in the courts, the press, and business). The only other leaders who can match or surpass the resources of expresidents are other ex-presidents or, if the party is in power, the sitting president. Sometimes incumbents lead the campaign to block the return of an ex-president (Venezuela 1988, Argentina 2003, Panama 2004); at other times, they simply acquiesce (Haiti 2000, Guatemala 2003). So unless the regime is restrictive (a policy option available to Is) or parties are sufficiently strong, ex-presidents face an advantage in elections.

\section{Two Responses To Strong Parties}

If the argument holds that crises in parties lead to ex-presidents, the converse should be true as well: stable, more institutionalized parties should discourage ex-presidents. The reason is that in more institutionalized parties, by definition, more avenues exist for alternative party leaders to compete with ex-presidents (Stokes 2001; Levitsky and 
Cameron 2003; Siavelis and Morgenstern 2004). Returning ex-presidents can respond to barriers originated by parties either by desisting or by breaking away. The "divergent" cases of Chile's Eduardo Frei in 2004 and Venezuela's Rafael Caldera in 1992 are illustrative. ${ }^{16}$

Frei signaled interest in running for office in July 2004. Initially, he enjoyed many advantages. He held a prominent institutional office (senador vitalicio). He was popular both within his party (the Christian Democrats) and with the political left; polls placed him among the three most popular precandidatos (Centro de Estudios Públicos 2004). He was also relatively popular with the electorate as a whole: his administration concluded with 49 percent approval and only 26 percent disapproval (Centro de Estudios Públicos 2004). He had strong allies in congress (e.g., Senators Mariano Ruíz-Esquide and Carmen Frei and Deputies Exequiel Silva and Jorge Burgos) and in the business sector. He decided to launch a comeback campaign because he believed that his party was heading toward a catastrophe by contemplating nominating a woman, Soledad Alvear (Correa 2004).

Party-based factors frustrated Frei's plans, however. Frei failed to obtain the support of any leading member of the party. The party's president, Adolfo Zaldivar, opposed him. Even his former allies, the socalled circulo de hierro (iron circle), the very same people who helped Frei get elected in 1994 and govern, failed to support his candidacy in 2004 (Silva and Guerra 2004). This lack of support was no surprise, given that the Christian Democratic Party is one of the most institutionalized in Latin America and that it enjoyed very high approval ratings in 2004 (which always lessens crises in parties). Facing a "lonely crusade," Frei quit the race in January 2005, in his words, "to maintain the unity of the party" (Yáñez 2005).

Like Frei, Caldera in 1992 was a senador vitalicio, and was popular within his party, COPEI, and across the nation, due to his outspoken opposition to President Pérez's market reforms. COPEI in early 1992 was not as strong as the Christian Democrats in Chile in the 2000s, but it was not moribund, either. In 1991-92, COPEI fared strongly in midterm elections, increasing its governorships from seven to ten, which suggested that it was well poised to win the 1993 presidential election. As is expected of popular, institutionalized parties, party leaders (e.g., Eduardo Fernández) rose to challenge Caldera. Rather than desist or compete in primaries, as Fernández suggested, Caldera decided to break away from COPEI (see Ellner 1996). He founded a new party, Convergencia; took away some of COPEI's leaders and voters; and sought an alliance with small leftist parties.

Caldera's defection caused havoc, not just inside COPEI, which never recovered, but also in Venezuela's party system. Caldera's return led to party fragmentation, a minority government, and policy incoherence. 
This institutional erosion is a predictable consequence of ex-presidential comebacks. Before developing this point, let us explore how party crises affect newcomers.

\section{Party Crises and Newcomers}

Whereas ex-presidents exploit party crises to stage comebacks, newcomers use them to steal newly available constituencies. When large parties collapse, especially in the context of political decentralization, which opens opportunities for new parties (Sabatini 2003), they leave a pool of voters available for political mobilization (Domínguez and Giraldo 1996). Examples of newcomers and low-experience candidates emerging in the context of ruling or opposition party collapse include Vargas Llosa and Fujimori in 1990, Toledo in 2000, and Humala in 2006 (Peru); Chávez in 1998 (Venezuela); Carrió in 2001 (Argentina); Elhers in 1996, Gutiérrez in 2002, and Correa in 2006 (Ecuador); and Morales in 2002 (Bolivia).

While many newcomers and low-experience candidates campaign as independents, a few try to take the reins of an existing party, provided that there is a viable party available. In making this decision, the candidate's economic background seems to play a role. Newcomers and lowexperience candidates who come from nonprivileged groups tend to avoid the party route (e.g., Antonio Saca in El Salvador). Moreover, instances of parties accepting newcomers are rare, which pushes newcomers to eschew the party route altogether. For instance, in Panama 1999, after banker Alberto Vallarino lost the primary elections for the Partido Arnulfista (PA) to Mireya Moscoso (widow of former President Arnulfo Arias), he resigned and ran for president with the endorsement of smaller parties. Parties resist newcomers for the same reason they resist ex-presidents: they are organizations full of career politicians waiting their turn to lead. Career party leaders disdain rivals who have already had their chance (ex-presidents) and those who have not paid their dues (newcomers and low-experience candidates).

Thus, environments in which major parties are getting stronger are less fecund for newcomers. This may explain why Brazil has been somewhat exempt from this phenomenon: in the 1990s, Brazil saw the strengthening of both the ruling party and the main opposition party, the PT, with the latter becoming the most "highly bureaucratized party" and the most connected to "organized interests" in Brazil (Hunter and Power 2007; Samuels 2008).

\section{SYMBIOTIC AND INTERACTIVE EFFECTS}

The causal connection between party crisis, ex-presidents, and newcomers can be more complex than the linear argument outlined so far. 
Figure 1. Voter Characteristics and the Challenges Faced by Aspiring Ex-presidents

\begin{tabular}{lcc}
\hline \hline Accepts XP's values & $\begin{array}{c}\text { Risk-Averse } \\
\text { I. }\end{array}$ & $\begin{array}{c}\text { Risk Taker } \\
\text { II. }\end{array}$ \\
& XP's core support & $\begin{array}{c}\text { Other party members } \\
\text { supporting new leaders }\end{array}$ \\
\hline Rejects XP's values & III. & IV. \\
& $\begin{array}{c}\text { Voters who support } \\
\text { traditional } \\
\text { opposition parties }\end{array}$ & $\begin{array}{c}\text { Voters who support } \\
\text { new parties }\end{array}$ \\
\hline \hline
\end{tabular}

More often, the connection is symbiotic. Party crises precipitate the rise of ex-presidents, but ex-presidents can also precipitate party crises, as happened under Caldera. Crises, in turn, can trigger the emergence of newcomers. To appreciate this sequence of events, it helps to explore the effects of XPs' comeback efforts.

\section{Electoral Challenges for Ex-presidents}

Despite their unrivaled political assets, ex-presidents do not exactly sail smoothly back into office. Recovering the presidency presents challenges. In confronting these challenges, ex-presidents often end up deinstitutionalizing and polarizing the political system. To illustrate this outcome, let us classify the electorate in two dimensions, each representing a different way of approaching political candidates. The first dimension is appetite for risk or change. Voters can be either risk-taking, comfortable trying new and untested options, or they can be risk-averse, apprehensive about new ideas and leaders. The second dimension is affinity with the values embraced by, or associated with, a presidential candidate. Voters can be either sympathetic or averse to the ex-president's ideology and record in office.

Figure 1 illustrates the four possible combinations of voters that emerge by combining risk propensity and value affinity. Ex-presidents start the race with one core support group: voters aligned with the expresident's values and showing little appetite for change (in the form of a completely new candidate, quadrant I). The problem with this core constituency is that it is seldom large enough to win office. Even ex-presidents with highly successful records in office will face the challenge of luring voters who are sympathetic but nonetheless eager to embrace the risk of supporting untested leaders (quadrant II), or those who disagree with the XP's values (quadrant III). It is in reaching out to these two quadrants that ex-presidents cause disruptions in the political system. 
The first group that ex-presidents will try to court is quadrant II, voters who belong to or sympathize with the ex-president's own party but support new candidates. These voters are disinclined to support the XP, not so much because they reject the XP's values, but because they long for new faces. Whether parties will offer new faces to choose from may depend, as has been argued, on the party's degree of institutionalization.

The best option that XPs have to capture quadrant II is, therefore, to impede the rise of alternative leaders within their parties. Often, expresidents conclude that the best way to do this is to tinker with the rules of the party. The task of capturing quadrant II, then, compels expresidents to erode the party's institutionality. This behavior infuriates existing party leaders, who rightly conclude that ex-presidents are hurting their career prospects. As a result, returning presidents usually unleash bitter intraparty conflicts.

Bolivia is a good illustration of this phenomenon. ${ }^{17}$ Between 1989 and 2005, Bolivia had five presidential elections, each with at least one ex-president obtaining more than 10 percent of the vote (see table 4). Hugo Banzer was perhaps the most persistent ex-president, trying three consecutive times until he finally succeeded in 1997. Each time he faced challengers within his own party, Acción Democrática Nacionalista $(\mathrm{ADN})$. Banzer responded by tinkering with the internal party rules repeatedly, including postponing primaries and other elections (May 1980, February 1992, 1995, May 2000, August 2001), changing the party's estatutos (October 1992, 1993, 1994), designating candidates or leaders without elections (May 1980, February 1995, August 2000), and establishing unclear electoral procedures (June 1987, 1991, 1992, August 1993, 1997, 1998, October 2000).

It is often argued that leaders like Banzer, who develop personal cults within their parties, rarely face internal challenges. If that were the case, procedural maneuvers like those Banzer used would be rare. They are not. These maneuvers are what enable leaders to perpetuate their command over parties.

Similar examples of leader-induced institutional volatility can be found in Banzer's main opposition party, the Movimiento Nacionalista Revolucionario, led by Sánchez de Lozada from 1990 to 2003. Soon after becoming president in 1993, Sánchez de Lozada began to plot his perpetuation as party leader. His tactics included a failed attempt to change the constitution to allow for re-election, having himself re-elected as party leader by avoiding direct primaries, selecting his successor presidential candidates through dedazo (personal choice), and changing party statutes to extend his term as party president.

Changes in Bolivia's electoral rules and institutions since 1985 are well known (Domingo 2005; Madrid 2005; Mayorga 2005), but changes inside parties are less known and just as dramatic. In trying to capture 
quadrant II, ex-presidents abuse their party's internal rules. This can wreck parties. For ADN, it led to at least eight major episodes of polarization and defection between 1985 and 2002 (October 1985, September 1990, December 1991, February and November 1992, June 1993, December 1994, and July 2002). For the MNR, Sánchez de Lozada provoked the most serious defections in the party's history.

Exceptions to this wreckage effect exist, but they are rare, and depend mostly on the party's status. When the party is completely collapsed (i.e., quadrant II is virtually empty), the return of an ex-president might revive the party. For instance, Alan García in Peru pulled his party, APRA, from achieving 1.38 percent of the vote in 2000 to 25.8 percent in the first round of the 2001 election. In most other cases, returning ex-presidents cause havoc within their parties, and possibly with other parties as well.

The other challenge that ex-presidents confront is reaching out to voters who reject the ex-president's values; namely, the opposition (quadrant III). Meeting this challenge also causes ex-presidents to engage in deinstitutionalizing practices. Three typical practices are what may be called extreme makeovers, shark attacks, and pacts with the devil.

Extreme makeovers entail hiding or disguising career disasters. Most ex-presidents come to the electoral race with major embarrassments in their resumes (Joaquín Balaguer and Aristide were known for using fraud and thugs; Ríos Montt and Dési Bouterse for massacres; Menem, Pérez, and Sánchez de Lozada for corruption and obstruction of justice; Caldera for intolerance of dissent; García for mishandling terrorism and economic crises; Jaime Paz Zamora for drug trafficking). Their electoral challenge, then, is to "erase" those blemishes from the record, or even from people's recollections. Daniel Ortega is a perfect contemporary example. In the 1980s, he led a regime that incarcerated six thousand to ten thousand political prisoners and provoked hyperinflation, and he himself faced accusations of stealing money from the Central Bank, redistributing mansions to himself and friends, and sexually abusing his stepdaughter. In seeking a comeback, Ortega began to camouflage his record. He started campaigning wearing white (rather than red) in the early 1990s, and adopted the campaign slogan "Peace, Love, and Reconciliation" for 2006. He even selected a former Contra leader as his running mate and formed an alliance with the Catholic Church and Evangelicals to outlaw abortions.

Shark attacks mean going for the kill against incumbents at the smell of blood. When incumbent presidents get into some kind of legal or political problem, ex-presidents entertaining re-election often become the most vocal proponents of immediate resignation, impeachment, and in some cases, even coups. Thus Caldera in 1992 famously defended Chávez's 1992 coup and spent the rest of Pérez's term working to expe- 
dite his impeachment. Sánchez de Lozada in 2001 was one of the first opposition leaders to call for Banzer's resignation when Banzer's approval ratings sank. In 1998, the Ecuadorian Congress received a letter from three ex-presidents (Osvaldo Hurtado, Rodrigo Borja, and León Febres Cordero) demanding the impeachment of Abdalá Bucaram less than six months after he took office (Selverston 1997). In 1999, as newly elected governor of the Brazilian state of Minas Gerais, ex-president Itamar Franco defaulted on his state's debts, triggering a major currency crisis, in what appeared to be an act of revenge against President Fernando Henrique Cardoso for legalizing immediate re-election and thereby frustrating Franco's comeback efforts.

Shark attacks can be so fierce that incumbent presidents have been known to respond by forming alliances with other ex-presidents to survive in office. When ex-president Febres Cordero initiated impeachment procedures against sitting president Lucio Gutiérrez in Ecuador in 2004, the latter sought a last-minute alliance with indicted ex-president Bucaram.

Pacts with the devil are situations in which ex-presidents collude with old enemies, including other ex-presidents. Again, Daniel Ortega is a good example. In 1999, Ortega signed the so-called Pacto with President Arnoldo Alemán. The pact consisted in stacking Nicaragua's courts and commissions with cronies and altering the constitution to grant the president immunity from criminal prosecution. Ortega and Alemán used their control of the legislature to change the electoral rules, lowering the percentage required to win an election without a run-off from 45 percent to 40 percent, or 35 percent with a five-point lead. The pact allowed Ortega to stack party cadres throughout the bureaucracy, the judiciary, and the national electoral system (Close and Deonandan 2004; Feinberg 2006; Feinberg and Kurtz-Phelan 2006). Ortega and Alemán also awarded each other seats in parliament for life. Municipal electoral councils were created with the understanding that presidents and vice presidents would alternate between the Sandinistas and the PLC, Alemán's party (Close and Deonandan 2004). This FSLN-PLC alliance led to severe splits in each party. By the time Ortega was elected in 2006, only two out of nine former guerrilla leaders who ran Nicaragua in the 1980s remained loyal to him (San Martín 2006).

These three strategies are all meant to court voters in quadrant III. They seldom work. At best, they mostly split quadrant III. Some riskaverse voters may be persuaded, but others become so disgusted with what they perceive as self-serving manipulation of rules by traditional, discredited strongmen that they end up shifting to quadrant IV. Thus, expresidents staging a comeback give rise to a paradox: in their effort to appear trustworthy, ex-presidents may create more disgust with the establishment without necessarily convincing voters that they themselves 
are anti-establishment. They expand the population that is willing to take a political risk to achieve change; which, in turn, creates electoral opportunities for newcomers. Ex-presidents, therefore, engage in practices that paradoxically end up increasing the demand for their nemesis.

\section{Newcomers, Meanwhile}

Newcomers and low-experience candidates may benefit from ex-presidents' running for office, but they still confront formidable challenges. Despite their heterogeneity (including billionaire entrepreneurs, media personalities, military personnel, labor organizers, former guerrillas, salsa singers, clerics, and so on), newcomers all have thin political resumes. Their challenge is therefore to persuade voters to "hire" them without much of a record.

These candidates must capitalize on anti-establishment sentiment (quadrant IV). The problem is that this sentiment is normally not widespread enough to yield an electoral majority. So the newcomer must expand the size of the anti-establishment electorate. They achieve this by overstating the extent to which existing institutions and politicians are all discardable. Inadvertently, then, newcomers tend to emulate the ex-president's tactics: they fabricate connections to a glorious, precorruption past (Chávez's self-identification as heir to Bolivar), exaggerate the evils of the status quo (Correa calling congress "a toilet"), and flaunt their allegiance to historically marginalized groups (Toledo campaigning wearing indigenous robes; Ehlers in Ecuador mobilizing environmentalists; Morales in Bolivia embracing cocaleros; Lugo in Paraguay campaigning as "bishop for the poor"). Because of its intense traditionalism, nativism, and calls for sweeping change, the discourse of newcomers and low-experience candidates is simultaneously restorative and dismissive, conservative and radical.

Furthermore, when running as independents, newcomers' favorite and easiest targets are political parties (Roberts 2007), because they recognize that voters in Latin America disdain political parties usually more than other political institutions. In Ecuador in 2006, for example, Rafael Correa, punning on his last name, campaigned saying that he would use belts (correas) to whip the "dictatorship of political parties."

As with ex-presidents, however, these tactics can backfire. Hard as they may try, newcomers, like ex-presidents, rarely captivate all voters in quadrants II and III. More typical is that the quadrants end up splitting, as a result of a conservative counterreaction based on the idea that these anti-status quo positions are too extreme.

Thus, ex-presidents and newcomers end up generating electoral sentiments that, paradoxically, help each other. This explains cases like Venezuela and Bolivia, where an oversupply of ex-presidents in the 
1990s led to a demand for newcomers and low-experience candidates in the 2000s; and Peru, where an oversupply of newcomers in the 1990s led to an overdemand for ex-presidents in the 2000s. By mid-2003, opinion polls in Lima revealed that the three most popular politicians-the ones people were most likely to vote for-were all ex-presidents: Paniagua, Fujimori, and García (Datum Internacional 2003).

\section{LATIN America's NeOcaudillismo}

Three decades of economic and policy volatility (the 1970s through the 1990s) have produced anxiety, and consequently political disaffection, throughout Latin America. The Latin American electorate has responded to this anxiety just as any person would to losses or uncertainty: by seeking some "known quantity" (voting for ex-presidents) or by "gambling" (voting for newcomers).

The status of political parties helps explain the route chosen. Party crises lead to the rise of ex-presidents and newcomers; the rise of expresidents and newcomers can provoke or exacerbate party crises. In turn, the rise of ex-presidents can lead to the rise of newcomers.

Each of these escape routes offers some hope for democratic renewal. For instance, the return of ex-presidents and the entry of independents can reignite political and ideological competition and even resuscitate collapsed parties. Newcomers and low-experience candidates offer hope for previously excluded groups and thereby raise doubts about the long-held notion that Latin America's electoral systems are relatively impermeable (see Hellinger 1999).

But these democratic hopes are often dashed by the associated risks. In their bids for office, ex-presidents frequently bend or break existing rules. Both ex-presidents and newcomers adopt discourses and strategies that are, paradoxically for ex-presidents, effectively anti-establishment and frequently polarizing. If electorally successful, both ex-presidents and newcomers risk governability problems stemming from their isolation at the top and the institutional wreckage they either created or took advantage of in order to stage their comebacks.

The return of ex-presidents, clearly the more salient of these two escape routes, is the essence of the new caudillismo in Latin America. These ex-presidents are the modern incarnation of what Chevalier (1962) called Latin America's "man on horseback." Ex-presidents command formidable political resources, including a core of supporters, or "dependents," to borrow again from Chevalier. They also profit from the institutional links forged from their time in office. Like the old caudillos, today's ex-presidents use their political assets to transform themselves into "impressive monuments" (Hamill 1965). In their bids for office, they tinker with institutions to block leadership renewal within their own parties and, 
paradoxically, resort to anti-establishment discourses. The former leads to party deinstitutionalization, the latter to more cynicism from the public. As with the old caudillos, returning ex-presidents exacerbate the anxieties of opponents, raising the demand for their nemesis, newcomers.

Newcomers, in turn, also exaggerate the ills of the status quo; this scares and alienates many political organizations. Paradoxically, newcomers end up emulating caudillo tactics, inadvertently embodying the very same vices they claim to want to exorcise from the body politic.

This explanation for the rise of ex-presidents and newcomers helps explain why, once elected, these candidates are prone to governance problems. Re-elected ex-presidents risk generating the three conditions that, according to Valenzuela (2004), result in "truncated" presidencies. One is "double minorities": they are typically elected with less than majority support and end up with minority status in congress (the average vote for re-elected ex-presidents, excluding Aristide, is 37.6 percent, lower than the 41.1 percent average obtained by Latin American presidents since 1983 (Payne et al. 2002, 74). The other two conditions are polarized and thus uncooperative ruling parties, and polarized party systems. Although not all ex-presidents will face governance problems, the risks are real, especially in periods of economic austerity (e.g., Pérez, Aristide, Sánchez de Lozada). Elected independent newcomers face serious risks as well. They must live with the consequences of their anti-establishment electoral campaign - the radicalism of some mobilized supporters and the animosity of groups targeted for criticism. To survive, both the president and the warring organizations resort to corrosive tactics: the president becomes more exclusionary, the opponents less tolerant.

Democratic politics in the 1990s produced new institutional and political obstacles to old-fashioned caudillo politics: more effective constitutional restrictions on re-elections or the abuse of power, a generalized repudiation of excessive military involvement in politics, and stronger means for civil society to check power. Consequently, there is some reason to celebrate: two old vices of presidentialist politics in Latin America, continuismo in office and the return of caudillos through coups, are unquestionably mitigated.

Compare Latin America today with Cuba in the 1950s. Then, Cuba epitomized the worst vices of Latin America's turn-of-the-century caudillismo. The preferred route of ex-presidents was to stage coups (Fulgencio Batista, 1952) or to fund armed insurrection (Carlos Prío Socarrás in the mid-1950s); the preferred route for newcomers was to stage a radical revolution and abolish liberties (Fidel Castro, 1959-61). That expresidents and newcomers today avoid such blatantly illiberal behavior no doubt represents progress. One could also celebrate that many expresidents, even today, fail in their return bids, a testament to the capacity of the electorate and parties to act as caudillo filters. 
Yet Latin America is still the land of caudillos. These new caudillos may not promote coups, insurrections, or totalitarianism, but they still weaken parties, erode checks and balances, and scare adversaries. That Latin America remains a land of neocaudillos seems to be the result of a vicious equilibrium. Economic and political disruptions lead to rising demand for caudillos; the perpetuation of caudillos leads to more disruptions and, ultimately, to more caudillos. Observers may differ as to whether ex-presidents and newcomers represent hope or doom for Latin America. But there is no denying that despite what they profess, ex-presidents and newcomers represent risky gambles.

\section{Appendix 1: Presidential Candidates in LATIN AMERICA}

Table 6. Presidential Candidates in Latin America Winning More than 10 Percent of the Vote, 1988-2006

\begin{tabular}{|c|c|c|c|c|c|c|c|c|c|}
\hline & & & $\mathrm{XP}$ & XPN & LE & $\mathrm{N}$ & I & Total & Winner \\
\hline 1 & Argentina & 1989 & & & & & & 2 & \\
\hline 2 & & 1995 & & & & & 1 & 3 & \\
\hline 3 & & 1999 & & & & & & 3 & \\
\hline 4 & & 2003 & 2 & & 1 & & & 5 & $\mathrm{XP}$ \\
\hline 5 & Bolivia & 1989 & 1 & & & 1 & & 4 & \\
\hline 6 & & 1993 & 1 & & & 1 & & 4 & \\
\hline 7 & & 1997 & 2 & & 2 & & & 5 & XP \\
\hline 8 & & 2002 & 2 & & 1 & & & 4 & $\mathrm{XP}$ \\
\hline 9 & & 2005 & 1 & & & & & 2 & \\
\hline 10 & Brazil & 1989 & & & 1 & & & 3 & \\
\hline 11 & & 1994 & & & & & & 3 & \\
\hline 12 & & 1998 & & & & & 1 & 3 & \\
\hline 13 & & 2002 & & & & & & 3 & \\
\hline 14 & & 2006 & & & & & 1 & 2 & \\
\hline 15 & Chile & 1993 & & 2 & & & & 2 & XPN \\
\hline 16 & & 1999 & & & & & & 2 & \\
\hline 17 & & 2005 & & & & & & 3 & \\
\hline 18 & Colombia & 1990 & & & & 1 & & 3 & \\
\hline 19 & & 1994 & & 1 & & & & 3 & \\
\hline 20 & & 1998 & & 1 & & & & 3 & XPN \\
\hline 21 & & 2002 & & & & & & 2 & \\
\hline 22 & & 2006 & & & & & 1 & 3 & \\
\hline 23 & Costa Rica & 1990 & & 1 & & & & 2 & \\
\hline 24 & & 1994 & & 1 & & & & 2 & XPN \\
\hline 25 & & 1998 & & & & & & 2 & XPN \\
\hline 26 & & 2002 & & 1 & 1 & & & 3 & $\mathrm{LE}$ \\
\hline 27 & & 2006 & 1 & & & & & 2 & XP \\
\hline
\end{tabular}


Table 6. (continued)

\begin{tabular}{|c|c|c|c|c|c|c|c|c|c|}
\hline & & & $\mathrm{XP}$ & XPN & LE & $\mathrm{N}$ & I & Total & Winner \\
\hline 28 & Dominican & & & & & & & & \\
\hline & Republic & 1990 & 1 & & & & 1 & 3 & $\mathrm{XP}$ \\
\hline 29 & & 1994 & 1 & & & & 1 & 3 & $\mathrm{XP}$ \\
\hline 30 & & 1996 & & & & & & 3 & \\
\hline 31 & & 2000 & 1 & & & & & 3 & \\
\hline 32 & & 2004 & 1 & & & & 1 & 3 & $\mathrm{XP}$ \\
\hline 33 & Ecuador & 1992 & & & & & & 3 & \\
\hline 34 & & 1996 & & & & 1 & & 4 & \\
\hline 35 & & 1998 & 1 & & 1 & & & 2 & \\
\hline 36 & & 2002 & 1 & 1 & & 1 & & 6 & $\mathrm{~N}$ \\
\hline 37 & & 2006 & & 1 & 1 & & & 4 & \\
\hline 38 & El Salvador & 1989 & & & & & & 2 & \\
\hline 39 & & 1994 & & & & & & 3 & \\
\hline 40 & & 1999 & & & 1 & & & 3 & \\
\hline 41 & & 2004 & & & & 1 & & 2 & $\mathrm{~N}$ \\
\hline 42 & Guatemala & 1990 & & & & & & 4 & \\
\hline 43 & & 1995 & & & & & & 3 & \\
\hline 44 & & 1999 & & & & 1 & & 3 & \\
\hline 45 & & 2003 & 1 & & & & & 3 & \\
\hline 46 & Haiti & 1995 & & & & & & 1 & \\
\hline 47 & & 2000 & 1 & & & & & 1 & $\mathrm{XP}$ \\
\hline 48 & & 2006 & 2 & & & & & 2 & $\mathrm{XP}$ \\
\hline 49 & Honduras & 1989 & & & & & & 2 & \\
\hline 50 & & 1993 & & & & & & 2 & \\
\hline 51 & & 1997 & & & & & & 2 & \\
\hline 52 & & 2001 & & & & & & 2 & \\
\hline 53 & Jamaica & 1989 & 1 & & & & 1 & 2 & $\mathrm{XP}$ \\
\hline 54 & & 1992 & 1 & & & & 1 & 2 & \\
\hline 55 & & 1997 & 1 & & & & 1 & 2 & \\
\hline 56 & & 2002 & 1 & & & & 1 & 2 & \\
\hline 57 & Mexico & 1988 & & 1 & 1 & & & 3 & \\
\hline 58 & & 1994 & & 1 & & & & 3 & \\
\hline 59 & & 2000 & & 1 & & & & 3 & \\
\hline 60 & & 2006 & & & & & & 3 & \\
\hline 61 & Nicaragua & 1996 & 1 & & & & & 2 & \\
\hline 62 & & 2001 & 1 & & & & & 2 & \\
\hline 63 & & 2006 & 1 & & & & & 2 & $\mathrm{XP}$ \\
\hline 64 & Panama & 1989 & & & & 1 & & 2 & $\mathrm{~N}$ \\
\hline 65 & & 1994 & & 1 & & 1 & & 3 & \\
\hline 66 & & 1999 & & 2 & & 1 & & 3 & XPN \\
\hline 67 & & 2004 & 1 & 1 & & & & 3 & XPN \\
\hline
\end{tabular}


Table 6. (continued)

\begin{tabular}{|c|c|c|c|c|c|c|c|c|c|}
\hline & & & $\mathrm{XP}$ & XPN & $\mathrm{LE}$ & $\mathrm{N}$ & I & Total & Winner \\
\hline 68 & Paraguay & 1993 & & & & 1 & & 3 & \\
\hline 69 & & 1998 & & & & & & 2 & \\
\hline 70 & & 2003 & & & & 1 & & 3 & \\
\hline 71 & Peru & 1990 & & & & 2 & & 3 & $\mathrm{~N}$ \\
\hline 72 & & 1995 & & & 1 & & 1 & 2 & \\
\hline 73 & & 2000 & & & & 1 & 1 & 2 & \\
\hline 74 & & 2001 & 1 & & 1 & & & 3 & $\mathrm{LE}$ \\
\hline 75 & & 2006 & 1 & & & 1 & & 3 & $\mathrm{XP}$ \\
\hline 76 & Suriname & 1996 & & & & & 1 & 3 & \\
\hline 77 & & 2000 & 2 & & & & 1 & 3 & $\mathrm{XP}$ \\
\hline 78 & & 2005 & 2 & & & & 1 & 3 & \\
\hline 79 & Uruguay & 1989 & & & & & & 3 & \\
\hline 80 & & 1994 & 1 & & & 1 & & 3 & $\mathrm{XP}$ \\
\hline 81 & & 1999 & 1 & & & & & 3 & \\
\hline 82 & & 2004 & & & & & & 3 & \\
\hline 83 & Venezuela & 1988 & 1 & & & & & 2 & $\mathrm{XP}$ \\
\hline 84 & & 1993 & 1 & & & & & 3 & $\mathrm{XP}$ \\
\hline 85 & & 1998 & & & & 1 & & 2 & $\mathrm{~N}$ \\
\hline 86 & & 2000 & & & & & 1 & 2 & \\
\hline \multirow[t]{2}{*}{87} & & 2006 & & & & & 1 & 2 & \\
\hline & & & $\mathrm{XP}$ & XPN & LE & $\mathrm{N}$ & I & Total & \\
\hline Totals & & & 38 & 16 & 12 & 18 & 17 & 235 & \\
\hline
\end{tabular}

$\mathrm{XP}=$ Ex-president

$\mathrm{XPN}=$ Ex-president's name

LE $=$ Low Experience

$\mathrm{N}=$ Newcomer

$\mathrm{I}=$ Incumbent

Re-election of XP prohibited

I election prohibited

Source: Constitutional restrictions drawn from Payne et al. 2002, 79. 


\section{Appendix 2: Candidates for President or Prime Minister in Europe}

Table 7. Candidates for President or Prime Minister in Europe Obtaining More than 10 Percent of the Vote, 1998-2006

\begin{tabular}{|c|c|c|c|c|c|c|c|c|c|}
\hline & & & $\mathrm{XP}$ & XPN & LE & $\mathrm{N}$ & I & Total & Winner \\
\hline 1 & Austria & 1992 & & & & & & 3 & \\
\hline 2 & & 1998 & & & & 1 & 1 & 3 & \\
\hline 3 & & 2004 & & & & & & 2 & \\
\hline 4 & Belgium & 1991 & & & 1 & & & 4 & \\
\hline 5 & & 1995 & & & & & 1 & 5 & \\
\hline 6 & & 1999 & & & 1 & & & 4 & \\
\hline 7 & & 2003 & 1 & & 1 & & 1 & 6 & \\
\hline 8 & France & 1988 & & & & & 1 & 4 & \\
\hline 9 & & 1995 & & & & & & 4 & \\
\hline 10 & & 2002 & & & & & 1 & 3 & \\
\hline 11 & Germany & 1990 & & & 1 & & 1 & 2 & \\
\hline 12 & & 1994 & & & & & 1 & 2 & \\
\hline 13 & & 1998 & & & & & 1 & 2 & \\
\hline 14 & & 2002 & & & & & 1 & 2 & \\
\hline 15 & & 2005 & & & & & 1 & 2 & \\
\hline 16 & Italy & 1992 & 1 & & & & & 3 & \\
\hline 17 & & 1994 & & & 1 & 1 & & 4 & $\mathrm{~N}$ \\
\hline 18 & & 1996 & 1 & & & & & 4 & \\
\hline 19 & & 2001 & & & & & & 4 & \\
\hline 20 & & 2006 & 1 & & & & 1 & 3 & $\mathrm{XP}$ \\
\hline 21 & Netherlands & 1989 & & & & & & 3 & \\
\hline 22 & & 1994 & & & & & & 4 & \\
\hline 23 & & 1998 & & & & & 1 & 3 & \\
\hline 24 & & 2002 & & & 1 & 1 & & 4 & LE \\
\hline 25 & & 2003 & & & & & 1 & 3 & \\
\hline 26 & Norway & 1989 & & & 1 & & 1 & 4 & \\
\hline 27 & & 1993 & & & 2 & & & 3 & LE \\
\hline 28 & & 1997 & & & & & 1 & 4 & \\
\hline 29 & & 2001 & 2 & & & & & 5 & $\mathrm{XP}$ \\
\hline 30 & & 2005 & 1 & & 1 & & & 3 & $\mathrm{XP}$ \\
\hline 31 & Spain & 1989 & & & & & 1 & 2 & \\
\hline 32 & & 1993 & & & & & 1 & 2 & \\
\hline 33 & & 1996 & & & & & 1 & 3 & \\
\hline 34 & & 2000 & & & & & 1 & 2 & \\
\hline 35 & & 2004 & & & & & & 2 & \\
\hline
\end{tabular}


Table 7. (continued)

\begin{tabular}{|c|c|c|c|c|c|c|c|c|c|}
\hline & & & $\mathrm{XP}$ & XPN & LE & $\mathrm{N}$ & I & Total & Winner \\
\hline 36 & \multirow[t]{4}{*}{ Sweden } & 1991 & & & & & 1 & 2 & \multirow{4}{*}{$\mathrm{XP}$} \\
\hline 37 & & 1994 & 1 & & & & 1 & 2 & \\
\hline 38 & & 1998 & 1 & & & & & 4 & \\
\hline 39 & & 2002 & & & & & 1 & 3 & \\
\hline 40 & United & 1992 & & & & & 1 & 3 & \\
\hline 41 & Kingdom & 1997 & & & & & 1 & 3 & \\
\hline 42 & & 2001 & & & & & 1 & 3 & \\
\hline \multirow[t]{2}{*}{43} & & 2005 & & & & & 1 & 3 & \\
\hline & & & $\mathrm{XP}$ & XPN & LE & $\mathrm{N}$ & I & Total & \\
\hline \multicolumn{2}{|c|}{ Totals } & & 9 & 0 & 10 & 3 & 26 & 136 & \\
\hline
\end{tabular}

\section{NOTES}

I am grateful to John Carey, Miguel Angel Centeno, Kenneth Erickson, Jorge I. Domínguez, Steven Levitsky, M. Victoria Murillo, Peter Siavelis, Kurt Weyland, Deborah Yashar, and three external reviewers for comments on earlier versions. I am also grateful to my colleague Frank Westhoff for his help with statistics, and to Adrian Althoff and Gina Turrini for their research assistance.

1. For many years, most Latin American countries banned incumbents from running for office. But Peru in 1993, Argentina in 1994, Brazil in 1997, Venezuela in 1999, and Colombia in 2005 amended their constitutions to allow for the consecutive re-election of incumbents (see appendix 1).

2. In this study, the term ex-president also refers to ex-prime minister. While voters in some parliamentary systems vote for parties rather than figures, they often know who the party leaders are, and therefore can make good guesses about the figure likely to win the prime minister's seat, depending on which party wins.

3. In the period covered by this study, most Latin American constitutions allowed former presidents to run; the exceptions are Guatemala, Honduras, Mexico, Paraguay, Colombia before 2005, and Costa Rica before 2006.

4. In the notes that follow, two asterisks mean winner; one asterisk means runner-up. Argentina: Carlos Menem (2003)**, Adolfo Rodríguez Saa (2003); Bolivia: Hugo Banzer (1989)*, (1993)*, (1997)**, Gonzalo Sánchez de Lozada (2002)**, Jaime Paz Zamora (2002), Jorge Quiroga (2005)*; Costa Rica: Oscar Arias (2006)**; Dominican Republic: Juan Bosch (1990)*, (1994), Jacobo Maljuta (1990), Joaquín Balaguer (2000), Leonel Fernández (2004)**; Ecuador: Rodrigo Borja Cevallos (1998), (2002); Guatemala: José Efraín Ríos Montt (2003); Haiti: Jean-Bertrand Aristide (2000)**, René Préval (2006)***, Leslie Manigat (2006)*; Jamaica: Michael Manley (1989)**; Edward Seaga (1993)*, (1997)*, (2002)*; Nicaragua: Daniel Ortega (1996)* (2001)*, (2006)**; Panama: Guillermo Endara (2004)*; Peru: Alan García (2001)*, (2006)**; Suriname: Ronald Venetiaan $(2000)^{* *}$, Dési Bouterse $(2000)^{*},(2005)^{*}$, Jules Wijdenbosch (2005); Uruguay: 
Julio María Sanguinetti (1994)**, Luis Alberto Lacalle (1999); Venezuela: Carlos Andrés Pérez (1988)**, Rafael Caldera (1993)**. (Menem won the first round in 2003 but decided not to participate in the second round.)

5. Belgium: Jean-Luc Dehaene (2003); Italy: Arnaldo Forlani (1992)**, Silvio Berlusconi (1996)*, Romano Prodi (2006)**; Norway: Thorbjørn Jagland (2001)**, Kjell Magne Bondevik (2001); Sweden: Ingvar Carlsson (1994)**, Carl Bildt (1998)*. (Arnaldo Forlani, Italy 1992, and Thorbjørn Jagland, Norway 2001, came in first but did not become prime ministers.)

6. Chile: Eduardo Frei (1993)**, Arturo Alessandri (1993)*; Colombia: Andrés Pastrana (1994)*, (1998)*; Costa Rica: Rafael Calderón (1990***, José Figueres (1994)**, Rolando Arcaya Monge (2002)*; Ecuador: Jacobo Bucaram (2002), Fausto Gilmar Gutiérrez (2006); Mexico: Cuauhtémoc Cárdenas (1988)*, (1994), (2000); Panama: Mireya Moscoso (1994)*, (1999)**, Martín Torrijos (1999)*, $(2004)^{* * *}$.

7. Bolivia: Carlos Palenque (1989), Max Fernández (1993); Colombia: Antonio Navarro Wolf (1990); Ecuador: Freddy Ehlers (1996), Lucio Gutiérrez (2002)**; El Salvador: Antonio Saca (2002)**; Guatemala: Alvaro Colom (1999), Panama: Guillermo Endara, (1989)**, Rubén Blades (1994), Alberto Vallarino (1999); Paraguay: Domingo Laino (1989)*, Guillermo Caballero Vargas (1993), Pedro Fadul (2003); Peru: Mario Vargas Llosa (1990)*, Alberto Fujimori (1990)**, Alejandro Toledo (2000)*, Ollanta Humala (2006)*, Uruguay: Alberto Volante (1994)*; Venezuela: Hugo Chávez (1998)***

8. Austria: Gertaud Knoll (1998)*; Italy: Silvio Berlusconi (1994)**; Netherlands: Lijst Pim Fortuyn (2002)*. In this race, newcomer candidate Pim Fortuyn was assassinated nine days before the general election. His party obtained 17 percent of the vote, coming in second.

9. I am grateful to Frank Westhoff for his help with the quantitative analysis.

10. Several different measures were also tried; they yielded the same coefficient signs and fewer significant results than the model reported. These and other methodological issues are treated in Westhoff and Corrales 2008.

11. The formula is

$$
\log \left(\frac{\text { Normalized Vote }- \text { Lower Bound }}{\text { Upper Bound }- \text { Normalized Vote }}\right)=b_{0}+b_{1} x_{1}+b_{2} x_{2}+\ldots
$$

12. The standard formula used is enp $=\frac{1}{\Sigma \mathrm{p}_{1}^{2}}$

where $\mathrm{pi}=$ portion of (lower house) legislative seats held. For Brazil, vote share was used.

13. A statistical paper (Westhoff and Corrales 2008) with complete data sets for this study is available on the author's website, https://cms.amherst.edu/ users/C/jcorrales/forthcoming.

14. The Dominican Republic 1994, Panama 1989, Peru 2000, and all Haiti elections.

15. For an argument on how "typical," or representative, cases can fruitfully be used to test hypotheses, see Gerring 2007, 91-97.

16. On the use of divergent cases to test hypotheses, see Gerring 2007.

17. This section draws from Althoff 2005. 


\section{REFERENCES}

Alesina, Alberto. 1994. Political Models of Macroeconomic Policy and Fiscal Reform. In Voting for Reform: Democracy, Political Liberalization and Economic Adjustment, ed. Stephan Haggard and Steve B. Webb. Oxford: Oxford University Press. 37-60.

Althoff, Adrian. 2005. How Ex-presidents Survive: The Cases of Hugo Banzer and Gonzalo Sánchez de Lozada in Bolivia. Mimeograph. Amherst College.

Centro de Estudios Públicos. 2004. Estudio Nacional de Opinión Pública no. 48. Santiago, Chile, December. <www.cepchile.cl>

Chevalier, François. 1962. "Caudillos" et "caciques" en Amérique: contribution à l'étude des liens personnels. Bulletin Hispanique 64: Mélanges offerts à Marcel Bataillon par les Hispanistes Français. 30-47.

Close, David, and Kalowatie Deonandan, eds. 2004. Undoing Democracy: The Politics of Electoral Caudillismo. Lanham: Lexington Books.

Coppedge, Michael. 2003. Popular Sovereignty versus Liberal Democracy in Venezuela. In Constructing Democratic Governance, ed. Larry Diamond and Richard Gunther. Baltimore: Johns Hopkins University Press. 165-92.

Corrales, Javier. 2003. Market Reforms. In Constructing Democratic Governance in Latin America, ed. Jorge I. Domínguez and Michael Shifter. Baltimore: Johns Hopkins University Press. 74-99.

Correa, Raquel. 2004. "Quiero ser protagonista del futuro de Chile." Entrevista al ex-presidente Eduardo Frei. El Mercurio (Santiago), February 1.

Dalton, Russell J., and Martin P. Wattenberg. 1993. The Not So Simple Act of Voting. In Political Science: The State of the Discipline, vol. II., ed. A. W. Finifter. Washington, DC: American Political Science Association. 193-218.

Datum Internacional. 2003. Estudio de opinión pública en la Gran Lima. Lima, August 18.

Domingo, Pilar. 2005. Democracy and New Social Forces in Bolivia. Social Forces 83, 4: 1727-44.

Domínguez, Jorge I., and Jeanne Kinney Giraldo. 1996. Conclusion: Parties, Institutions, and Market Reforms in Constructing Democracies. In Constructing Democratic Governance, ed. Domínguez and Abraham Lowenthal. Baltimore: Johns Hopkins University Press. 3-41.

Downs, Anthony. 1957. An Economic Theory of Democracy. New York: Harper and Row.

Edwards, Sebastian. 1995. Crisis and Reform in Latin America: From Despair to Hope. Washington, DC: World Bank.

Ellner, Steve. 1996. Political Party Factionalism and Democracy in Venezuela. Latin American Perspectives 23, 90: 87-109.

Feinberg, Richard. 2006. Nicaragua Elections: Too Close To Call. Latin Business Chronicle, October 16.

Feinberg, Richard, and Daniel Kurtz-Phelan. 2006. Nicaragua Between Caudillismo and Modernity: The Sandinistas Redux? World Policy Journal 23, 2 (Summer): 76-84.

Fernández, Raquel, and Dani Rodrik. 1991. Resistance to Reform: Status Quo Bias in the Presence of Individual-Specific Uncertainty. American Economic Review 81, 5: 1146-55. 
Freedom House. Various years. Freedom in the World. <www.freedomhouse.org> Accessed January 25, 2007.

Gerring, John. 2007. Case Study Research: Principles and Practices. New York: Cambridge University Press.

Gunther, Richard, José Ramón Montero, and Mariano Torcal. 2007. Democracy and Intermediation: Some Attitudinal and Behavioural Dimensions. In Democracy, Intermediation, and Voting in Four Continents, ed. Gunther, Montero, and Hans-Jürgen Puhle. New York: Oxford University Press. $29-73$.

Hagopian, Frances. 1998. Democracy and Political Representation in Latin America in the 1990s: Pause, Reorganization, or Decline? In Fault Lines of Democracy in Post-Transition Latin America, ed. Felipe Agüero and Jeffrey Stark. Coral Gables: North-South Center Press. 99-143.

— . 2005. Conclusions: Government Performance, Political Representation, and Public Perceptions of Contemporary Democracy in Latin America. In The Third Wave of Democratization in Latin America: Advances and Setbacks, ed. Hagopian and Scott P. Mainwaring. New York: Cambridge University Press. 319-62.

Hamill, Hugh M., Jr. 1965. Introduction. In Dictatorship in Spanish America, ed. Hamill. New York: Alfred A. Knopf. 3-25.

Hellinger, Daniel. 1999. Electoral and Party Politics. In Developments in Latin American Political Economy, ed. Julia Buxton and Nicola Phillips. Manchester, UK: Manchester University Press. 49-71.

Huber, Evelyne, and Fred Solt. 2004. Successes and Failures of Neoliberalism. Latin American Research Review 39, 3: 150-64.

Huber, Evelyne, and John D. Stephens. 2001. Development and Crisis of the Welfare State: Parties and Policies in Global Markets. Chicago: University of Chicago Press.

Hunter, Wendy, and Timothy J. Power. 2007. Rewarding Lula: Executive Power, Social Policy, and the Brazilian Elections of 2006. Latin American Politics and Society 49, 1 (Spring): 1-30.

Huntington, Samuel J. 1968. Political Order in Changing Societies. New Haven: Yale University Press.

Kucynski, Pedro-Pablo. 1988. Latin American Debt. Baltimore: Johns Hopkins University Press.

Levitsky, Steven, and Maxwell A. Cameron. 2003. Democracy Without Parties? Political Parties and Regime Change in Fujimori's Peru. Latin American Politics and Society 45, 3 (Fall): 1-33.

Linz, Juan. 1994. Presidential or Parliamentary Democracy: Does It Make a Difference? In The Failure of Presidential Democracy: Comparative Perspectives, ed. Linz and Arturo Valenzuela. Baltimore: Johns Hopkins University Press. 3-87.

Lora, Eduardo, and Ugo Panizza. 2003. The Future of Structural Reform. Journal of Democracy 14, 2: 123-33.

Madrid, Raúl. 2005. Indigenous Voters and Party System Fragmentation in Latin America. Electoral Studies 24, 4 (December): 689-707.

Mainwaring, Scott P. 2006a. The Crisis of Democratic Representation in the Andes. Journal of Democracy 17: 13-27. 
- 2006b. State Deficiencies, Party Competition, and Confidence in Democratic Representation in the Andes. In The Crisis of Democratic Representation in the Andes, ed. Mainwaring, Ana María Bejarano, and Eduardo Pizarro Leongómez. Stanford: Stanford University Press. $295-345$.

Mayorga, René Antonio. 2005. Bolivia's Democracy at the Crossroads. In The Third Wave of Democratization in Latin America: Advances and Setbacks, ed. Frances Hagopian and Scott P. Mainwaring. New York: Cambridge University Press. 149-78.

Molina, José. 2000. Comportamiento electoral en Venezuela 1998-2000: cambio y continuidad. Revista Venezolana de Economía y Ciencias Sociales 6, 3: $45-68$.

Payne, Mark J., Daniel G. Zovatto, Ferando Carrillo Flórez, and Andrés Allamand. 2002. Democracies in Development: Politics and Reform in Latin America. Washington, DC: Inter-American Development Bank.

Popkin, Samuel L. 1992. The Reasoning Voter. Chicago: University of Chicago Press.

Roberts, Kenneth M. 2007. Latin America's Populist Revival. SAIS Review 27, 1 (Winter-Spring): 3-15.

Roberts, Kenneth, and Erik Wibbels. 1999. Party Systems and Electoral Volatility in Latin America: A Test of Economic, Institutional, and Structural Explanations. American Political Science Review 93, 3: 575-90.

Rodrik, Dani. 1996. Understanding Economic Policy Reform. Journal of Economic Literature 34, 1: 9-41.

Sabatini, Christopher. 2003. Decentralization and Political Parties. Journal of Democracy 14, 2: 138-50.

Samuels, David. 2008. Democracy Under Lula. In Constructing Democratic Governance, 3rd edition, ed. Jorge I. Domínguez and Michael Shifter. Baltimore: Johns Hopkins University Press.

San Martín, Nancy. 2006. Ortega's Old Guard Has Mostly Splintered. Miami Herald, December 14, 20A.

Schedler, Andreas, Mark F. Plattner, and Larry Diamond, eds. 1999. The SelfRestraining State: Power and Accountability in New Democracies. Boulder: Lynne Reinner.

Selverston, Melina. 1997. The Unraveling of a Presidency. NACLA Report on the Americas 30, 6: 11-12.

Sheahan, John. 2002. Alternative Models of Capitalism in Latin America. In Models of Capitalism: Lessons for Latin America, ed. Evelyne Huber. University Park: Pennsylvania State University Press. 25-52.

Siavelis, Peter M., and Scott Morgenstern. 2004. Political Recruitment and Candidate Selection in Latin America: A Framework for Analysis. Paper presented at the 25th International Congress of the Latin American Studies Association, Las Vegas, NV, October 6-8.

Silva, Rodrigo, and Mónica Guerra. 2004. Senador vitalicio Eduardo Frei dice no ser candidato presidencial aun. El Mercurio (Santiago), October 18.

Singh, Anoop. 2006. Macroeconomic Volatility: The Policy Lessons from Latin America. Occasional Paper 06/166. Washington, DC: International Monetary Fund. July. 
Singh, Anoop, Agnès Belaisch, Charles Collyns, Paula de Masi, Reva Krieger, Guy Meredith, and Robert Rennhack. 2005. Stabilization and Reform in Latin America: A Macroeconomic Perspective on the Experience Since the Early 1990s. Occasional Paper 238. Washington, DC: International Monetary Fund. Stokes, Susan. 2001. Mandates and Democracy: Neoliberalism by Surprise in Latin America. New York: Cambridge University Press.

Sturzenegger, Federico, and Jeromin Zettelmeyer. 2007. Debt Default and Lessons from a Decade of Crisis. Cambridge: MIT Press.

Teitel, Simon, ed. 1992. Towards a New Development Strategy for Latin America: Pathways from Hirschman's Thought. Washington, DC: Inter-American Development Bank.

Thaler, R. 1980. Towards a Positive Theory of Consumer Choice. Journal of Economic Behavior and Organization 1: 39-60.

Valenzuela, Arturo. 2004. Latin American Presidencies Interrupted. Journal of Democracy 15, 4: 5-19.

Westhoff, Frank, and Javier Corrales. 2008. Statistical Appendix for "Latin America's Neocaudillismo." <https://cms.amherst.edu/users/C/jcorrales/forthcoming>

Weyland, Kurt. 2002. The Politics of Market Reform in Fragile Democracies: Argentina, Brazil, Peru, and Venezuela. Princeton: Princeton University Press.

Williamson, John, and Pedro-Pablo Kucynski, eds. 2003. After the Washington Consensus: Restarting Growth and Reform in Latin America. Washington, DC: Institute for International Economics.

World Bank. 2002. Globalization, Growth, and Poverty: Building an Inclusive World Economy. Washington, DC: World Bank.

Yáñez, Nelly. 2005. Ex presidente Frei se baja de la carrera por la presidencia. El Mercurio (Santiago), January 5.

Zettelmeyer, Jeromin. 2006. Growth and Reforms in Latin America: A Survey of Facts and Arguments. Working Paper 06/210. Washington, DC: International Monetary Fund. September. 